\title{
Environmental Factors Controlling Methane Emissions from Peatlands in Northern Minnesota
}

\author{
NANCY B. DISE ${ }^{1}$ AND EVILLE GORHAM
}

Department of Ecology, Evolution and Behavior, University of Minnesota, Minneapolis

\author{
ELON S. VERRY
}

U.S. Forest Senice, North Central Forest Experiment Station, Grand Rapids, Minnesota

\begin{abstract}
Controls on methane emission from peatlands in northern Minnesota were investigated by correlation wo environmental variables and by field manipulation. From September 1988 through September 1990, methane flux measurements were made at weekly to monthly intervals at six sites in the Marcell Experimental Forest, northern Minnesota (two open bog sites, two forested bog sites, a poor fen, and a fen lagg). Flux was related to water table position and peat temperature with simple correlations at individual sites and multiple regression on all sites together. The effect of water table was also investigated experimentally in "bog corrals" (open-ended metal enclosures set in the peat) in which water table was antificially raised to the surface in the driest peatland. Temperature largely controlled variation in flux within individual ecosystems at Marcell, but hydrology distinguished between-site variation. Water table position, peat temperature, and degree of peat humification explained $91 \%$ of the variance in $\log \mathrm{CH}_{4}$ flux, predicted annual methane emission from individual wetlands successfully, and predicted the change in flux due to the water table manipulation. Raising the water table in the bog corrals by an average of $6 \mathrm{~cm}$ in autumn 1989 and $10 \mathrm{~cm}$ in summer 1990 increased emission by $2.5 x$ and $2.2 x$. respectively. Just as expanding the scale of investigation from a single habitat in a wetland to several wetlands necessitates incorporation of additional variables to explain flux (water table, peat characteristics), modeling flux from several wetland regions, if possible, will require the addition of climate parameters.
\end{abstract}

\section{INTRODUCTION}

An increase in the concentration of atmospheric methane, documented through ice core analyses as beginning about 400 years ago and recently (since 1970) accelerating to a rate of about $1 \%$ per year, has engendered a number of studies to better quantify global methane sources and sinks (summaries by $A$ selmann and Cnutzen [1989]), Mathew's and Fung, [1987], and Cicerone and Oremlond [1988]. After cathon dioxide, methane is the most important radiatively active ("greenhouse") gas, adsorbing infared radiation strongly in the $7.66 \mu \mathrm{m}$ band. Methane accounts for an estimated $12 \%$ of total greenhouse warming [Hansen et al., 1989] and since concentrations of the gas are increasing at twice the rate of carbon dioxide, its relative importance is expected to increase in the future. Natural wetlands are one of the major sources of atmospheric methane, contributing an estimated $15-20 \%$ to the global budget [A selmann and Cruteen, 1989; Matthews and Fung, 1987].

Beyond identifying sources and sinks of methane, mitigation of emissions depends on understanding the factors that control its production and consumption. Temperature, water table position, and substrate nutrient quality have all been shown to affect methane flux from northem peatlands [e.g., Roulet et al., 1992; Crill et al.,

'Currently at U.S. Forest Service North Central Forest Experiment Station, Grand Rapids, Minnesota

1993 by the American Geophysical Union.
1988; Moore and Knowles, 1989; Harriss and Sebacher, 1981], but the relationships are far from straightforward. In different studies some or even all of these factors have had no effect on flux. Most studies assess the effects of the environmental correlates individually; to our knowledge, only one [Roulet et al., 1992] has examined the interacting effects of both temperature and water table simultaneously. Since there are very few studies of flux over a full annual cycle [e.g. Whalen and Reeburgh, 1992], possible seasonal shifts in controls may be missed. Finally, inferring causality from statistical correlations between flux and environmental variables is hampered by a scarcity of experimental data on the effect of the variables individually.

In this study, methane emission was measured for 2 years from five different peatland ecosystems (six sites) in northem Minnesota and correlated with peat temperature, water table position, and degree of peat humification. The relationship established between flux and these factors was compared to results from a field manipulation experiment in which the water table was artificially raised in three experimental plots within the driest peatland. It was also used to test if annual methane emission from a site could be successfully predicted by knowing only peat temperature and water table position. The aim of this project was to distinguish the main factors that influence methane flux within single wetlands and among different wetlands in a region.

\section{METHODS}

Study Siles

The study peatlands are located within Marcell Experimental Forest (USDA Forest Service) in northem Minnesota $\left(47^{\circ} 32^{\prime} \mathrm{N}, 93^{\circ} 28^{\prime}\right.$ 
W). The region is characterized by small upland watersheds forested with aspen (Populus tremuloides) and birch (Betula papynfera) surrounding peaty lowlands [ $V$ emy, 1975; Boelter and Verry, 1977]. The lowlands contain both nutrient-poor bogs, which are fed by precipitation, and fens, which receive some mineral nutrients from groundwater or subsurface flow (and thus support a more diverse flora). Black spruce (Picea mariana) and tamarack (Larix laricina) are common in the forested bogs, as are sedges (Canex -spp.) and alder (A lnus nigosa) in the fens. Both bogs and fens at Marcell have a ground cover of sphagnum, in particular Sphagnum angustifolium, Sphagnum capillifolium, and Sphagnum magellanicum.

Mean annual temperature at Marcell $(1961-1990)$ is $3.1^{\circ} \mathrm{C}$ and mean annual precipitation is $77 \mathrm{~cm}$, of which about $30 \%$ is snow. Average summer (June to August) temperature for 1988, 1989, and 1990 was $2.7^{\circ} \mathrm{C}, 0.9^{\circ} \mathrm{C}$, and $0.9^{\circ} \mathrm{C}$ warmer, respectively, than the 1961 to 1990 summer average of $17.4^{\circ} \mathrm{C}$. Total precipitation for 1988,1989 , and 1990 was $18 \%$ above average, average, and $23 \%$ below average, respectively. The summers of 1988 and 1989 were wet and the summer of 1990 was very dry $(7 \mathrm{~cm}$ total precipitation in July and August). Record wet months occurred in August and September of 1988 and June of 1989 , and record warm months "occurred in June and July of 1988 and January of 1990 .

The three peatlands selected for intensive study were Bog S-2, a 3-ha perched bog completely forested with black spruce and ringed by an alder fen (referred to as the fen lagg), Bog S-4, a partially open 8-ha bog with a small central pond, and Junction Fen. a weakly minerotrophic, open 5 - ha fen. The sites are described in detail elsewhere [Crill et al., 1988; Dise, 1993]. Fluxes were measured at weekly to monthly intervals from a $35-\mathrm{cm}-\mathrm{high}$ sphagnum bog hummock ("collar 3"), a bog hollow ("collar 4"), and a depression in the fen lagg ("collar 5") in Bog S-2, from two locations on a floating sphagnum mat near the open water in Bog S-4 ("collar 1" and "collar 2"), and one location in the carex/sphagnum community of Junction Fen ("collar 6"). The sites at collars 1 and 3 were identical to those used in an April to June 1986 survey of methane tlux at Marcell [Crill et al., 1988]; collars 2 and 4 were located near sites measured in that earlier study.
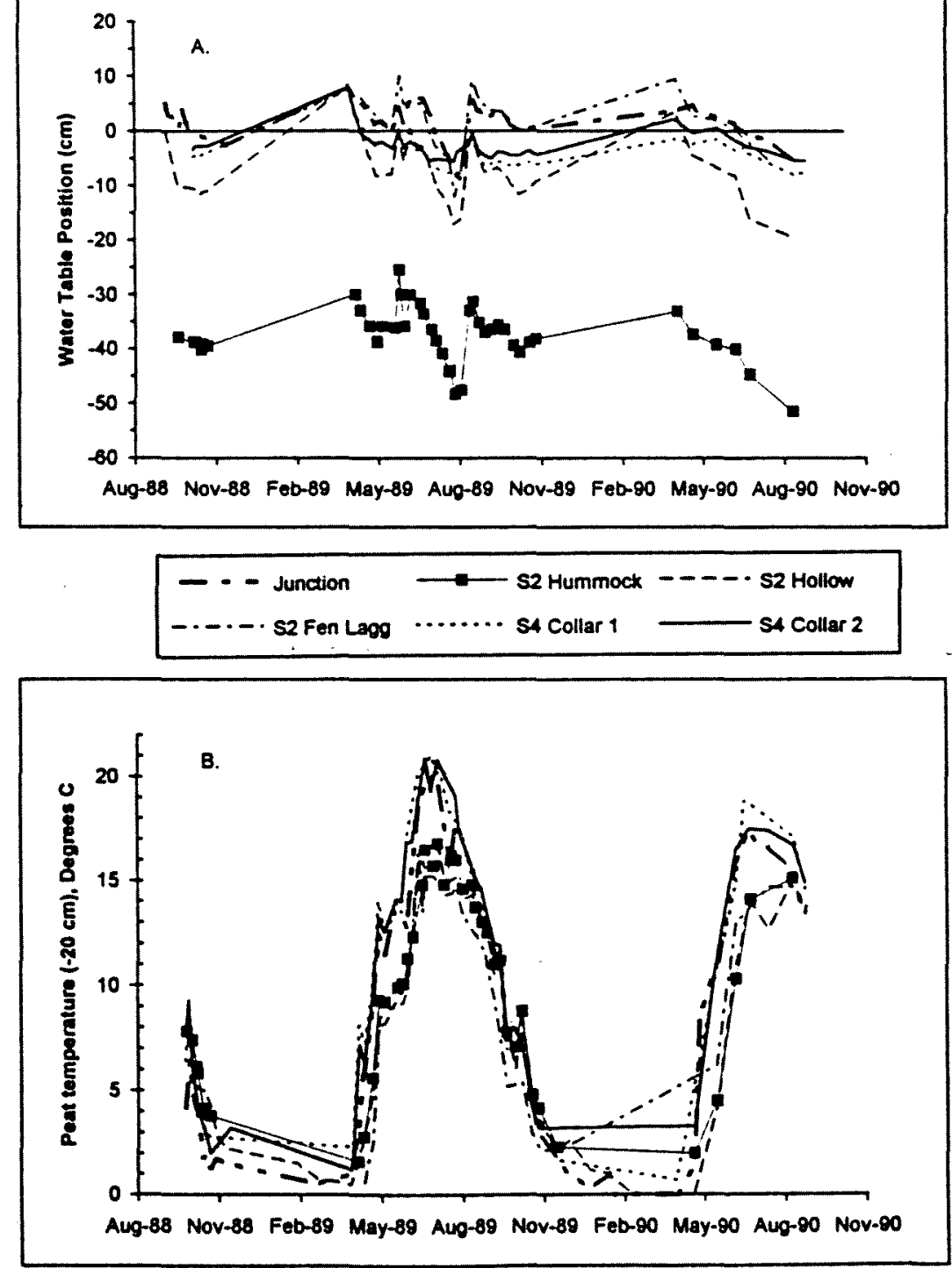

Fig. 1. (a) Water table position (peat surface at hollows is equal to 0 ) and (b). 20 -cm peat temperature, Marcell Experimental Forest survey sites, September 1988 to September 1990. Symbols show measurement dates for hummock site. 


\section{Flux Measurements}

Methane flux from five of the six sites (hereafter called "survey sites") was measured at monthly intervals in the winter, and weekly to fortnightly intervals during the rest of the year, from September 1988 to September 1990 . Measurements at the S-2 fen lagg began 8 months later than the others, in May 1989. Sampling was most frequent in the year April 1989 to April 1990. Flux was measured in the field by fitting an aluminum chamber (dimensions $63 \times 64 \times$ $37 \mathrm{~cm}$ ) over an aluminum collar set into the site. Head space samples from the chamber were taken every $4 \mathrm{~min}$ for $20 \mathrm{~min}$ with $60-\mathrm{ml}$ plastic syringes, resulting in five grab samples. Samples were analyzed with a Shimadzu Mini 2 gas chromatograph with a flame ionization detector, antached to a Hewlett-Packard HP-3390A integrator. Methane flux was calculated from the slope of the concentration change over time corrected to the surface area covered by the chamber and the "effective volume" of the chamber (total volume of chamber reduced by the volume occupied by the peat surface and any standing water, or water equivalent of the snow in winter). The regression coefficient and the intercept (near ambient $\mathrm{CH}_{4}$ ) were used as checks on the measurement; approximately $10 \%$ of the measurements were rejected. Methane concentrations increased linearly in the chambers over periods of 2 47 hours in 10 test measurements spanning all four seasons [Dise, 1991]. This method is also in good agreement with both flowthrough chamber techniques [Crill et al., 1988; $B$ anlett et al., 1988] and tower-based estimates integrating over a larger area [ $B$ anlett et al., 1989; V'ema et al., 1992 ].

Within-site variability was evaluated from June through October 1989 by measuring weekly flux from four replicate collars in Junction Fen (including collar 6) and Bog S-2 (including collar 4). These measurements were repeated monthly during the snow-free season for the rest of the study. Coefficients of variation averaged
$33 \%$ for replicates in Bog S-2 (range 10-82\%) and $45 \%$ in Junction Fen (range 18-82\%), somewhat lower than the values of $50-100 \%$ commonly reported. The survey site fluxes were consistently within the range of the other replicates [Dise, 1993].

Bog comals

To isolate the influence of hydrology on methane flux, a field experiment was designed-to manipulate water level within a subsection of Bog S-2. Three "bog corrals," open-ended, square, 11 gauge sheet metal enclosures (dimensions $1.2 \times 1.2 \times 1.5 \mathrm{~m}$ ), were installed in January 1989 by chain sawing the outline of the corral in the frozen peat and hammering the corral vertically in to the peat until only $30 \mathrm{~cm}$ was exposed above the surface. Lateral drainage was thus cut off and because the lower peat is quite dense, vertical drainage was very slow. One collar was installed in a hollow in each corral. After 1 month of background $\mathrm{CH}_{4}$ measurements, water level in the corrals was raised to the surface on July 8, 1989, and kept there through November. Surface water level was maintained as needed by adding bog water from an adjacent well or removing pooled rainwater. These adjustments were small $( \pm 1$ $\mathrm{cm}$ ) and only infrequently made (every 1 to 2 weeks); the experiment was largely self-sustaining. Three other hollow sites in S-2 were established as controls, and all six were measured weekly. The bog corral experiments were repeated on a limited schedule the following year.

\section{Ancillany Measurements}

At each sampling site, temperature was measured using an Omega $\mathrm{HH}-72 \mathrm{~T}$ thermistor with a thermocouple probe at the end of a $50-\mathrm{cm}$ tube. A temperature profile at surface, 2, 10, 20,30, and $40 \mathrm{~cm}$ was recorded for all survey sites, and temperatures at surface

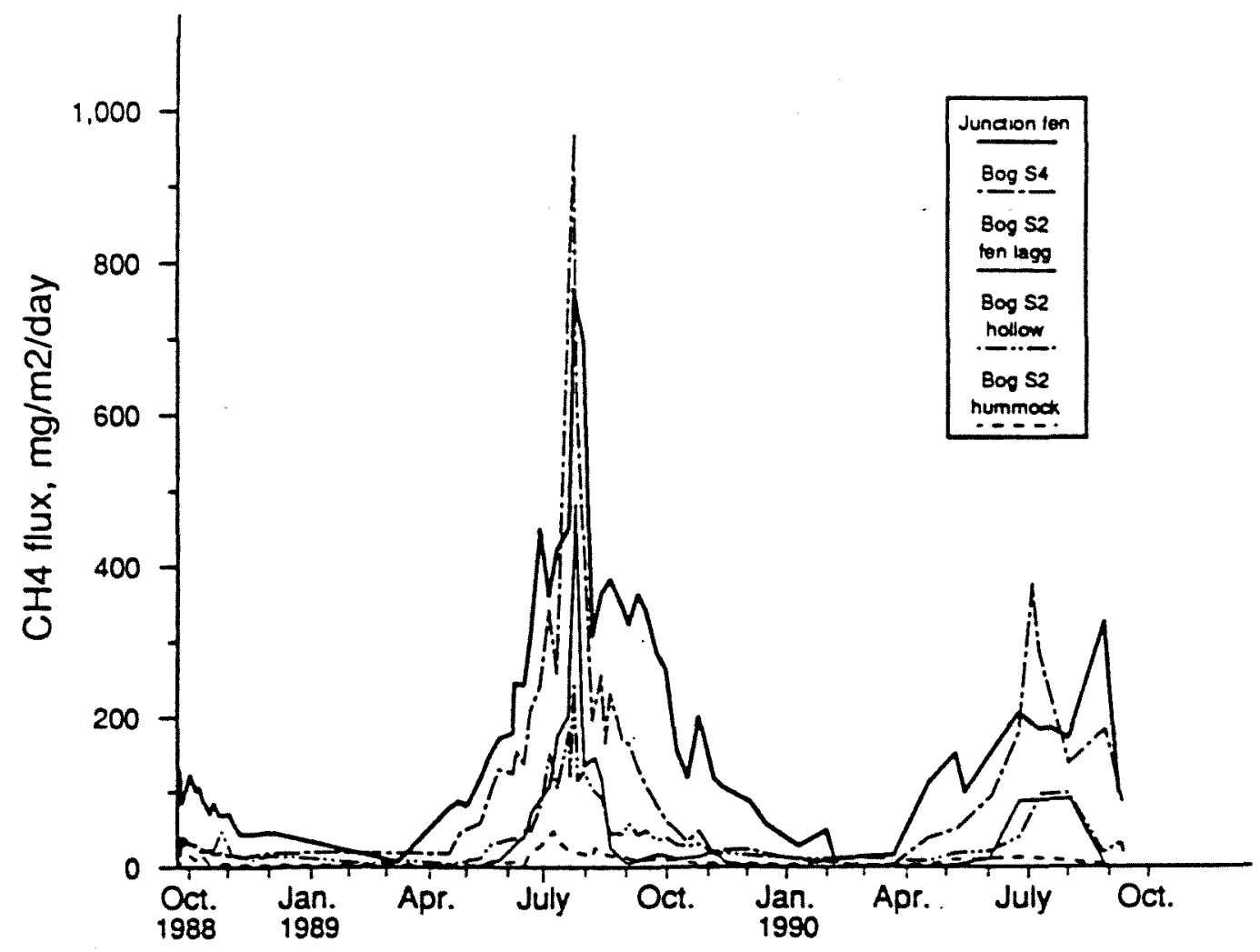

Fig. 2. Methane hux. survey sites, September 1988 to September 1990, from Dise [1993]. 
and $10 \mathrm{~cm}$ were recorded for the bog corral and control sites. Water table depth was determined during each flux sampling by referencing the water line to a stake in small wells dug at each of the sites. All water table measurements are reported as relative to the peat surface at hollows. Pore water samples were extracted manually at the desired depth through a stainless steel tube fitted onto the stop cock of a $60-\mathrm{cm}^{3}$ plastic syringe. Dissolved methane was stripped from the sample in the lab by introducing an equal volume of air and shaking the sample for 5 minutes [Crill et al., 1988]. Headspace concentrations were corrected for $\mathrm{CH}_{4}$ in the air. Gas samples were also collected from the submerged stems of water arum (Calla palustris) at the fen lagg site using a $60-\mathrm{cm}^{3}$ syringe equipped with a needle. The sample was drawn by piercing the underwater stem and pulling air from the central pith. Samples of $20-40 \mathrm{~cm}^{3}$ could regularly be collected from the plants in this way.

\section{Data A nalyses}

Annual fluxes were calculated by integrating daily fluxes over the year. Stepwise multiple linear regression was used to relate methane flux to environmental variables. Since a logarithmic transformation normalized the data and greatly reduced variance heteroscedasticity [Sokal and Rohlf, 1981], $\log \left(\mathrm{CH}_{4}\right.$ llux +1$)$ was used as the dependent variable (a value of 1 was added to each flux before transformation because the data include some zero values). Independent variables in the stepwise regression were peat temperature (surface, $2,10,20,30$, and $40 \mathrm{~cm}$ ), water table position from the peat surface in each collar, 3-week running average water table, 1 month running average water table, year of measurement (dummy variable; Devore and Peck [1986]), season (dummy variable), bog versus fen (dummy variable), and Von Post

TABLE 1. Relationships among Methane Emission ( $\mathrm{mg} \mathrm{CH}_{4} \mathrm{~m}^{-2} \mathrm{~d}^{-4}$ ), Peat Temperature, and Water Table Position, Marcell Experimental Forest sites

\begin{tabular}{|c|c|c|c|}
\hline Site & Regression & $N$. & $r^{2}$ \\
\hline Bog S-2-hummock & $\begin{aligned} \log (\text { flux }+1) & =0.042(\mathrm{~T} 20)+0.609 \\
\log (\text { flux }+1) & =0.0509(\mathrm{~T} 20)+0.025(\mathrm{MWT}) \\
& +1.44\end{aligned}$ & $\begin{array}{l}43 \\
29\end{array}$ & $\begin{array}{l}0.50 \\
0.59\end{array}$ \\
\hline Bog S-2-hollow & $\log (f l u x+1)=0.054(T 10)+1.04$ & 59 & 0.74 \\
\hline Bog S-2-fen lagg & $\log ($ flux +1$)=0.085(\mathrm{~T} 10)+0.476$ & 31 & 0.38 \\
\hline Bog S-4-collar 1 & $\log ($ flux +1$)=0.082(\mathrm{~T} 20)+0.995$ & 45 & 0.84 \\
\hline Bog S-4-collar 2 & $\log ($ flux +1$)=0.069(\mathrm{~T} 20)+1.08$ & 41 & 0.88 \\
\hline Junction Fen & $\log ($ flux +1$)=0.059(\mathrm{~T} 30)+1.60$ & 52 & 0.71 \\
\hline
\end{tabular}

$T$ is the peat temperature at the depth $(\mathrm{cm})$ at which the best-fit regression line was obtained. MWT is the one-month running mean water table. All regression lines are significant at $p<0.01$.

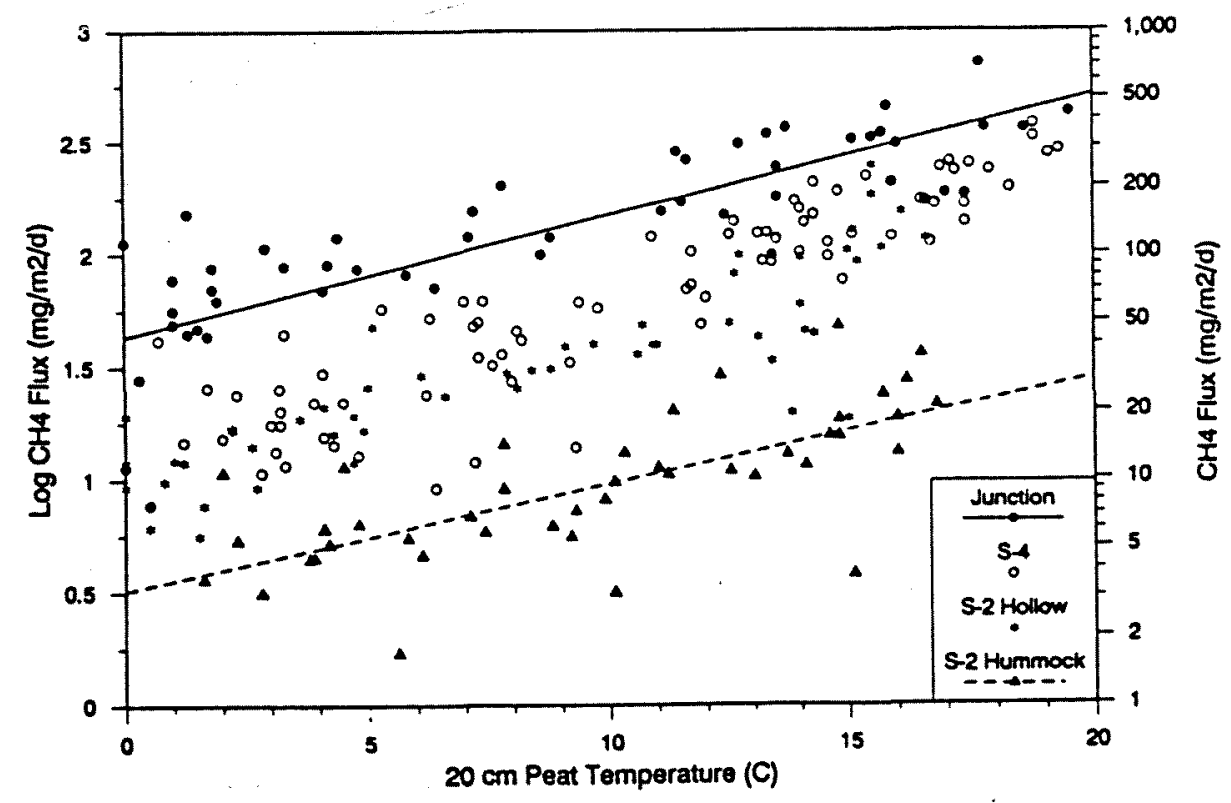

Fig. 3. Peat temperature versus $\log \mathrm{CH}_{4}$ flux, survey sites. Regression lines for Junction Fen and Bog S-2hummock are shown. 
humification scale (ranked variable, Sokal and Rohlf [1981]). The last variable is an index of the degree of peat decomposition [Stomeck and Silc. 1977]. It differentiates peat types on the basis of evidence from intact plant structures, clarity of pore water, and muckiness; the range is from completely unhumified and muck free (1) to completely humified (10). In this study, the index ranged from 2 in Junction Fen to 4 in Bog S-2.

\section{RESULTS}

\section{Seasonal Trends in Environmental Variables}

Water table position for all six sites showed the same annual pattem, with high spring levels declining through the summer and fall, except for a fairly sharp increase in early fall 1989 (Figure la). The five different ecosystem types could be segregated by water table into three groups: Junction Fen and the S-2 fen lagg were the wettest, the hummock site in Bog S-2 was the driest. and the S-2hollow and $\mathrm{S}-4$ sites were intermediate. The fact that the $\mathrm{S}-4$ sites are on a floating mat is clearly shown by the water table pattem, as the amplitude of the drop in summer water table is only about half that of the other sites.

Peat temperatures could be segregated into two broad categories: the cooler sites in the forested Bog S-2 and the warmer sites in the open $\mathrm{S}-4$ bog and Junction Fen (Figure $1 b$ ). Temperature differences between open and forested sites were most

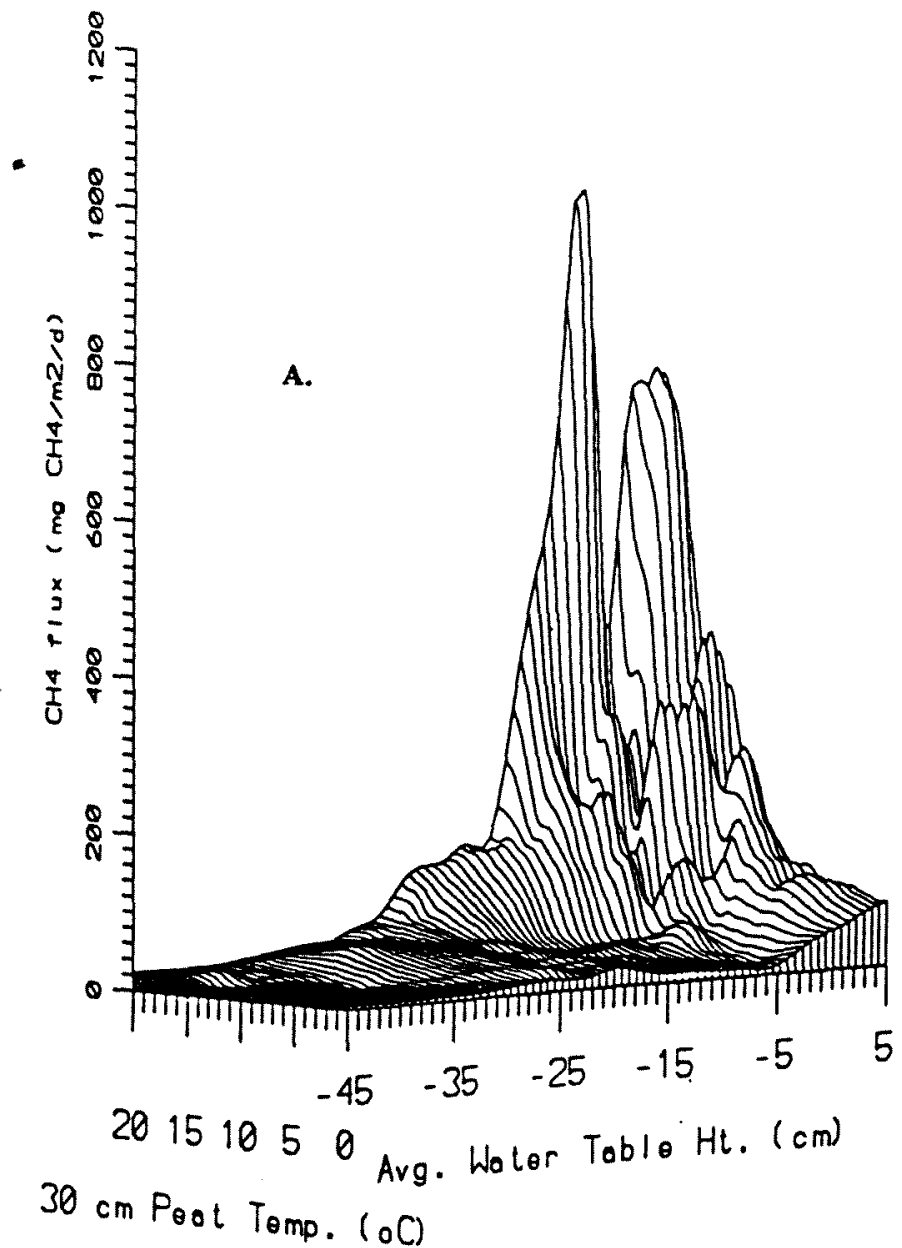

pronounced in July, when they amounted to $2^{\circ}-3^{\circ} \mathrm{C}$ at $20 \mathrm{~cm}$ depth. Subsurface peat temperature was a lagged $(1-2$ weeks at $20 \mathrm{~cm})$ and dampened record of air temperature. Temperature at $10 \mathrm{~cm}$ in the S. 2 bog corrals averaged about $1^{\circ}$ warmer than the controls in the summer and $1^{\circ}$ cooler than the controls in the autumn, perhaps due to heat conduction by the corrals.

\section{Methane Flux Fronı Sunvey Sites}

Detailed descriptions of spatial and temporal patterns of methane emission from the survey sites are presented elsewhere [Dise, 1991, 1993]. In brief, emission differed significantly among the three peatlands ( $S-2, S-4$, Junction) and among the three different habitats wihin S-2 (hummock, hollow, lagg). The magnitude of seasonal fluxes consistently followed the rank order Junction $>$ Bog S-4 $>$ Bog S-2 hollow $>$ Bog S-2 hummock, paralleling the gradient from wettest to driest site (Figure 2). Flux peaked in mid-July at all sites in 1989, then gradually decreased through fall and winter. Emission was 30-40\% lower in 1990 and showed no pronounced summer peak. Methane was emitted all year, including winter, by all sites except the fen lagg. One negative flux (methane consumption) was recorded from the 320 survey site measurements over 2 years: a value of $-0.8 \mathrm{mg} \mathrm{CH}_{4} \mathrm{~m}^{-2}$ $\mathrm{d}^{-1}$ measured from the S-2 fen lagg on August 31, 1990. Annual

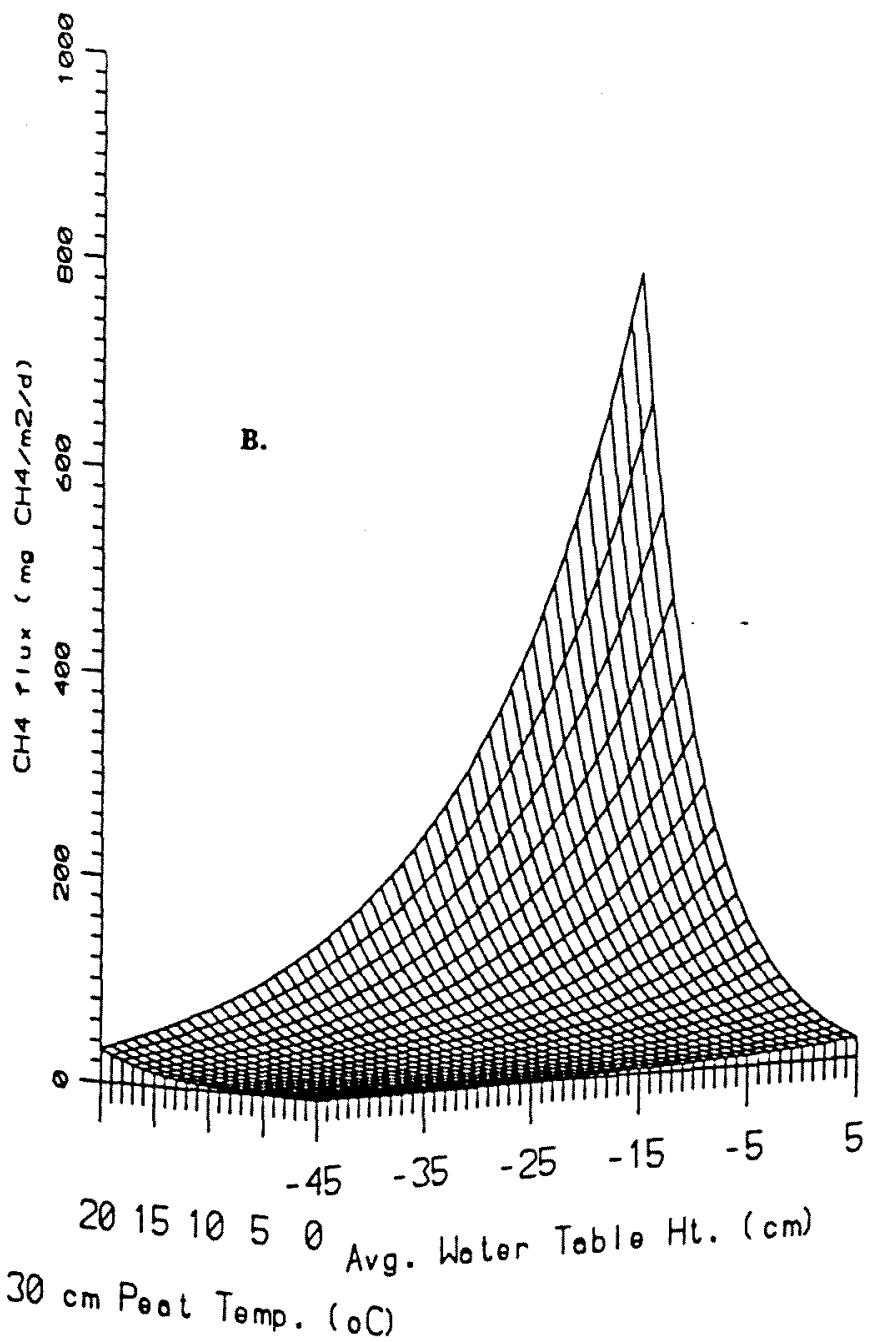

Fig. 4. Methane flux versus peat temperature $(30 \mathrm{~cm}$ ) and water table height (monthly running average). (a) Strvey data (Kriging interpolation used to create surface). Peaks in surface curves are July pulses of methane in Junction Fen and Bog S-4. (b) Regression model of the survey data (model C in Appendix). 
flux (April 1989 to April 1990) ranged from $3.5 \mathrm{~g} \mathrm{CH}_{4} \mathrm{~m}^{-2}$ in Bog S-2 to $65.7 \mathrm{~g} \mathrm{CH}_{4} \mathrm{~m}^{-2}$ in Junction Fen.

\section{Correlative Studies}

At each location $\mathrm{CH}_{4}$ flux correlated closely with temperature (Table 1). Only in the dry Bog S-2 hummock did addition of water table position improve the correlation significantly. The temperature correlation was highest in Bog $\mathrm{S}-4\left(\mathrm{r}^{2}=0.88\right)$ and lowest in the $S-2$ marginal fen $\left(r^{2}=0.38\right)$, where significant tluxes are, we believe, controlled primarily by plant transport (discussed below). The value of $Q_{10}$ over the range $5^{\circ}-15^{\circ} \mathrm{C}$ for spring, summer, and fall averaged 5.1 , being lowest (2.9) at $20 \mathrm{~cm}$ in the dry Bog S-2 hummock and highest (7.9) at $10 \mathrm{~cm}$ in the Bog S-2 fen lagg. Similar values have been reported during spring thaw from subarctic fens in Quebec [Moore and Knowles, 1990]. The $Q_{10}$ estimates from this study were lower than Crill et al.'s [1988] values of 5.4 to 13 for the same sites at Marcell, but their study was conducted during a warm and wet spring and early summer, when emission rates were high and increasing relatively rapidly. Restricting our data to the same dates as their. study gave comparable $Q_{10}$ values. When fluxes were split by season, temperature was again, with the exception of the S-2 hummock (in summer), the only factor that correlated significantly with methane flux. It is thus apparent that in the individual peatlands studied at Marcell, any effect of water table on flux is masked by the overriding influence of temperature.

The effect of a second factor became evident only when all of the sites were considered together (Figure 3 ). The regression lines between $\log$ flux and temperature were approximately parallel among sites and distinct: at any given temperature, drier sites had lower fluxes than wet sites. This relationship became obvious with a multiple regression (Figure 4); although $\mathrm{CH}_{4}$ flux at individual survey sites correlated only to temperature. water table position became the most important correlate when data from five sites (excluding the S-2 marginal fen) were pooled. The best fit multiple linear regression was

$\log \left(\mathrm{CH}_{4}+1\right)=0.0214(\mathrm{MWT})+0.0765(\mathrm{~T} 30)-0.154(\mathrm{VP})+1.63$

$$
R^{2}=0.91 \mathrm{n}=141 \quad \mathrm{p}<0.0001
$$

where flux was in units of $\mathrm{mg} \mathrm{CH} \mathrm{m}^{-2} \mathrm{~d}^{-1}$. MWT was the monthly running mean water table (measured once a week) in centimeters, $\mathrm{T}$ was ${ }^{\circ} \mathrm{C}$ at $30 \mathrm{~cm}$ depth, and VP was the Von Post humification scale value at $30 \mathrm{~cm}$ (model "A" in Appendix). Water table position accounted for $62 \%$ of variance, temperature $26 \%$. and humification only $2 \%$, perhaps because it did not differ much among locations. Water table position and temperature were uncorrelated in the model $\left(r^{2}=0.02\right)$. The same model resulted from either forward inclusion (in which variables are entered in to an initially empty model one at a time until the best fit model results) or backward deletion (where variables are sequentially deleted from an initially full model) and with randomly split halves of the data. When VP was left out of the multiple regression, vegetation type (bog or fen) became significant and also accounted for $2 \%$ of variance. When water table position measured on the same day as flux was used (rather than monthly running mean water table), the $R^{2}$ value dropped only slightly, to 0.88 , although the standard deviation was higher $(n=196, p<0.0001$, model $B$ in Appendix). Similar regression models were developed with slight variations in the independent variables for specific applications (in Appendix).
As expected, a split-data model did well in predicting methane emission from the other half of the data set $\left(r^{2}=0.91, n=71 . p<\right.$ 0.0001 . Appendix model $D$ used), with no apparent variance heterogeneity (Figure $5 a$ ). Back transforming to actual fluxes reduced the predictive value of the equation $\left(r^{2}=0.75\right)$ due to increasing variability with increasing magnitude of tluxes. Prediction of the geometric mean flux for each site, however. was excellent $\left(r^{2}=0.97\right.$. Figure $\left.5 b\right)$. The predictive value of similar regression models generated from the survey data declined with tirst, temporal, and then, spatial distance from the Marcell data. Thus a regression generated from 1989 data worked well in predicting 1990 fluxes $\left(\mathrm{r}^{2}=0.78, \mathrm{n}=19 . \mathrm{p}<0.0001\right.$, model $\mathrm{E}$ used), but the 1988 to 1990 data regression performed less well with Marcell data from 1986 [Crill et al, 1988] $\left(r^{2}=0.69 . \mathrm{n}=54\right.$, p < 0.0001 , model $F$ used) and least with data from quite different boreal peatlands in Alaska [Sebacher et al., 1986; S. Whalen, unpublished data $(1990)]\left(r^{2}=0.15, n=36, p<0.02\right.$, model $G$ used).

\section{Water Table Monipulation}

The influence of hydrology on methane emission at individual sites was demonstrated experimentally in the bog corrals (Figure 6). Fluxes from corrals and controls were not significantly different during the pre-treatment period and in the days immediately following. Raising and maintaining the water table in Bog S-2 at the peat surface from July 8 onward led, after a lag of more than 3 weeks, to distinctly higher $\mathrm{CH}_{4}$ fluxes (approximately double the controls). Between August 8 and November 7, 1989, total flux from enclosures was $9.5 \mathrm{~g} \mathrm{CH}_{4} \mathrm{~m}^{.2}$. In controls, where water table averaged $6.1 \mathrm{~cm}$ beneath the peat surtace, flux was $3.8 \mathrm{~g} \mathrm{CH}_{4} \mathrm{~m}^{-2}$, $40 \%$ of the enclosure flux. In 1990 (May 9 to August 31), flux from the corrals was $15.7 \mathrm{~g} \mathrm{~m}^{-2}$ versus $7.1 \mathrm{~g} \mathrm{~m}^{-2}$ from the controls ( $45 \%$ lower), with the average water table difference at $10.4 \mathrm{~cm}$. Paired t tests indicated these tlux differences were highly significant both years $(p<0.02)$. Although, as previously discussed, no relation between flux and water table position was found in the S-2 hollow site, water table height accounted for $34 \%$ of the variation in flux (in addition to $38 \%$ due to temperature) when considering the corrals and controls together in S-2. The fact that water table position became an important correlate with flux in S-2 hollows only when the bog corral data were included suggests that the part of the bog isolated by the corrals had. in effect, become a distinct habitat.

Since only $10-\mathrm{cm}$ peat temperature was measured in the manipulation experiments, a new regression model was developed from survey data to test flux predictions (using $10-\mathrm{cm}$ temperature instead of $30-\mathrm{cm}$ temperature, Appendix model $\mathrm{H}$ ). This model, generated from all the 1989 to 1990 survey data but not using corral/control data, successfully predicted both the geometric mean fluxes and the total fluxes from the corrals and controls in 1989 and 1990 (Figure $5 b$ ). It also reproduced the overall pattems of both the autumn decline in flux and the effect of the water table height (Figure 7), although the latter was not exactly replicated: the regression model predicted fluxes to be less responsive to the water table change than actually observed and more responsive to temperature (corrals were slightly warmer than controls in summer and cooler than controls in late autumn). This is not surprising considering the model is based on flux data from several different peatlands including wet ones (where the flux response to temperature changes is more pronounced than in S-2). The regression coefficients represent an averaging of responses from the different sites. 


\section{Estimating A nnual Emission}

Annual emission of methane at Marcell has been closely approximated by multiplying the geometric mean summer (June to August) methane flux by a time period of about 175 days [Dise, 1993]. We used this relationship together with the regression to predict annual methane flux from individual sites as follows: $\log$ flux was estimated from the regression for each site during each day between June 1 and August 31 in which water table and $30-\mathrm{cm}$ peat temperature measurements were available. Geometric mean summer flux was calculated by computing the antilog of the average of those values for each site, and finally, annual flux was estimated by multiplying the geometric mean flux by 175 . The result was compared to annual fluxes calculated by integration of measured values. To avoid predicting fluxes from a model calibrated on those same fluxes, we used two approaches: (1) a split-data technique to calculate annual fux from April 1, 1989 to March 31, 1990 (model D in Appendix used) and (2) a model using data from the first year to predict annual flux from the second year (model $E$ used). Since, with the first approach a model generated from one year was used to predict fluxes from that same year, within-site variability due to climate or biology was low and predicted flux was very close to measured flux (means of 27.9 and $31.5 \mathrm{~g} \mathrm{CH}_{4} \mathrm{~m}^{-2} \mathrm{yr}^{-1}$, respectively, Table 2). In the second case,
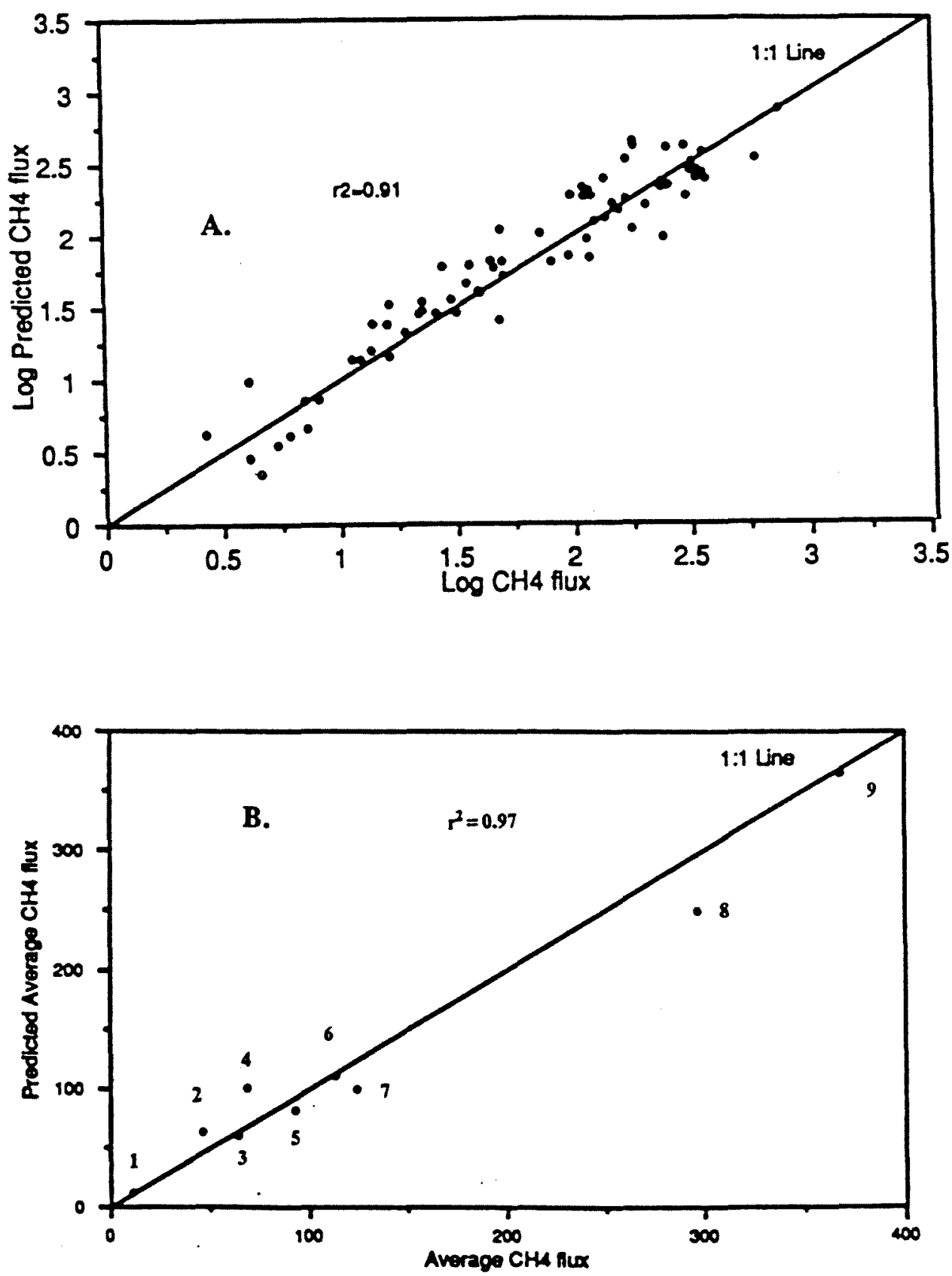

Fig. 5. Predicted versus measured methane flux, split data set (model D in Appendix; model $H$ for bog corrals and replicate collars). (a) Log flux, survey sites. (b) Geometric mean flux, May to November 1989 (except where noted). Sites are (1) Bog S-2 hummock, (2) Bog S-2 replicate collars, (3) Bog S-2 hollow, (4) Bog S-4 collar 2, (5) Bog S-2 bog corrals, (6) Bog S-4 collar 1, (7) Bog S-2 bog corrals (May to August 1990), (8) Junction Fen, and (9) Junction Fen replicate collars (June to September 1989). 


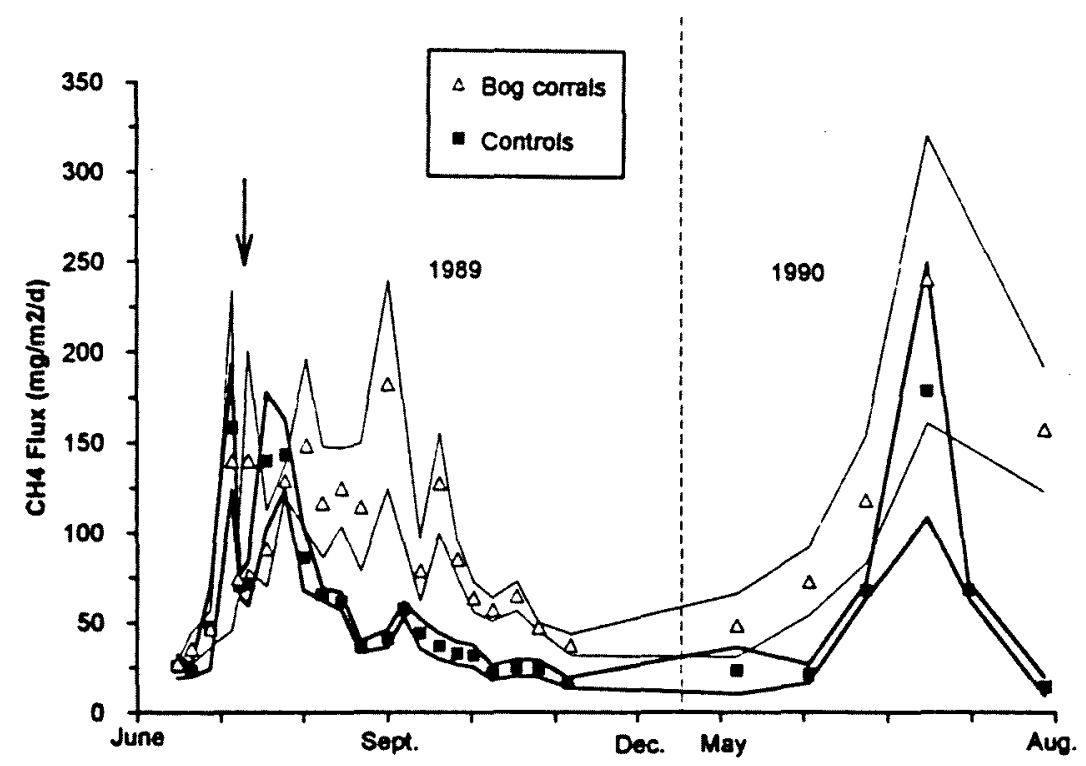

Fig. 6. Methane emission from S-2 bog corrals and controls. June 1989 to August 1990. Each point is the mean of 2-3 measurements, boundary lines are \pm 1 standard error of the mean. Arrow indicates start of experiment on July 8, 1989.

data generated from a wet year were used to predict flux from a dry year: as expected, predicted flux $\left(28.8 \mathrm{~g} \mathrm{CH}_{4} \mathrm{~m}^{-2} \mathrm{yr}^{-1}\right)$ was about one third higher than measured flux $\left(21.2 \mathrm{~g} \mathrm{CH}_{4} \mathrm{~m}^{-2} \mathrm{yr}^{-1}\right)$. Predictions for the wet sites were poorest because the model incorporated summer pulses in Junction and $S-4$, that were not observed the second year. Fluxes from the drier Bog S-2 were again predicted very well. It is clear that additional influences on flux from wet sites, not accounted for in the regression, need further investigation. These may include population dynamics of methanogens under optimal conditions, pulses of increased flux tied to a lowering of the water table [e.g., Moore et al., 1990; Dise, 1993] or decreases in atmospheric pressure [e.g., Mattson and Likens, 1990; N.J. Shurpali et al., Seasonal distribution of methane flux in a Minnesota peatland measured by eddy correlation, submitted to Joumal of Geophysical Research, 1993], ebullition, or the release of plant exudates as substrates for methanogenesis.

\section{Special Case: Plant Transport}

The pattem of annual methane emission from the fen lagg was unique among the six sites. Significant fluxes occurred only from carly June to late August, but during those 3 months such a large amount of methane was emitted $\left(11.2 \mathrm{~g} \mathrm{~m}^{-2}\right.$ or $90 \%$ of total annual flux) that the annual flux estimated from the lagg was very close to that of the hollow site in S-2, which emitted methane all year. A near-total cessation of methane emission occurred in the lagg in early September despite an autumn water table consistently at or slightly above the surface.

The unusual pattem of fluxes from this site and the relatively poor relationship between flux and either temperature or water table suggested that methane fluxes in the lagg may be strongly influenced by other factors. A likely candidate is emission through emergent macrophytes. Significant methane emission began in the lagg only when shoots of Calla palustris emerged in early May (Figure 8). Fluxes declined sharply with this plant's senescence in late August, suggesting that it provided conduits for $\mathrm{CH}_{4}$ transport. By allowing rapid passage through the many layers of surface. matted leaves and vegetation, as well as bypassing potential surface oxidation [Chanton and Dacey, 1992], methane was probably released much faster than by diffusion alone. Transport of methane has been shown in numerous aquatic plants including cultivated rice [Cicerone and Shefter. 1981], Typha latifolia (cattail) [Holzapfel-Pshom and Seiler, 1986; Sebacher et al., 1985], Nuphar luteum (yellow water lily) [Sebacher et al., 1985], and Peltandra virginica (arrow-arum) [Sebacher et al., 1985]. In the fen lagg. three measurements of methane concentration in submerged Calla stems averaged $916 \mathrm{mg} \mathrm{CH}_{4} \mathrm{~m}^{-3}$, within the range of concentration for those plants ranked highest in methane transport in one study [Sebacher et al., 1985]. Also supporting the transport hypothesis is the observation that pore water methane concentration $(30 \mathrm{~cm})$ in the lagg increased sharply in mid-September after the Calla died, a change that was not paralleled in the S-2 hollow site [Dise, 1991]. This sugmasts that a significant temperature drop occurred (methane solubinity increases with decreasing temperature), a large amount of organic substrate became available. and/or a major loss mechanism was discontinued. Temperature changes alone $\left(13.5^{\circ}\right.$ to $11.6^{\circ}$ from August 1 to September 13 ) were insufficient to account for the pore water $\left[\mathrm{CH}_{4}\right]$ increase, and we feel that the elimination of the main loss mechanism was the reason for the buildup. Similarly, $W$ ilson et al. [1989] reported a large springtime decrease in pore water methane concentration in a Virginia swamp accompanied by the emergence of the arrow-anum Peltandra which could not be attributed solely to a temperature increase [Chanton and Dacey, 1992].

In the autumn, after the senescence of the Calla, some methane may be released from this site by ebullition (Holzapfel-Pshom and Seiler, 1986; Chanton and Dacey, 1992]. Since it is highly unlikely that such episodic release would be detected from weekly chamber measurements, it is quite possible that the annual flux calculated from this site is an underestimate.

\section{DIsCussion}

This study used both correlation and experimentation to suggest possible controls on methane emission in Minnesota peatlands. That a significant correlation between flux and peat temperature 


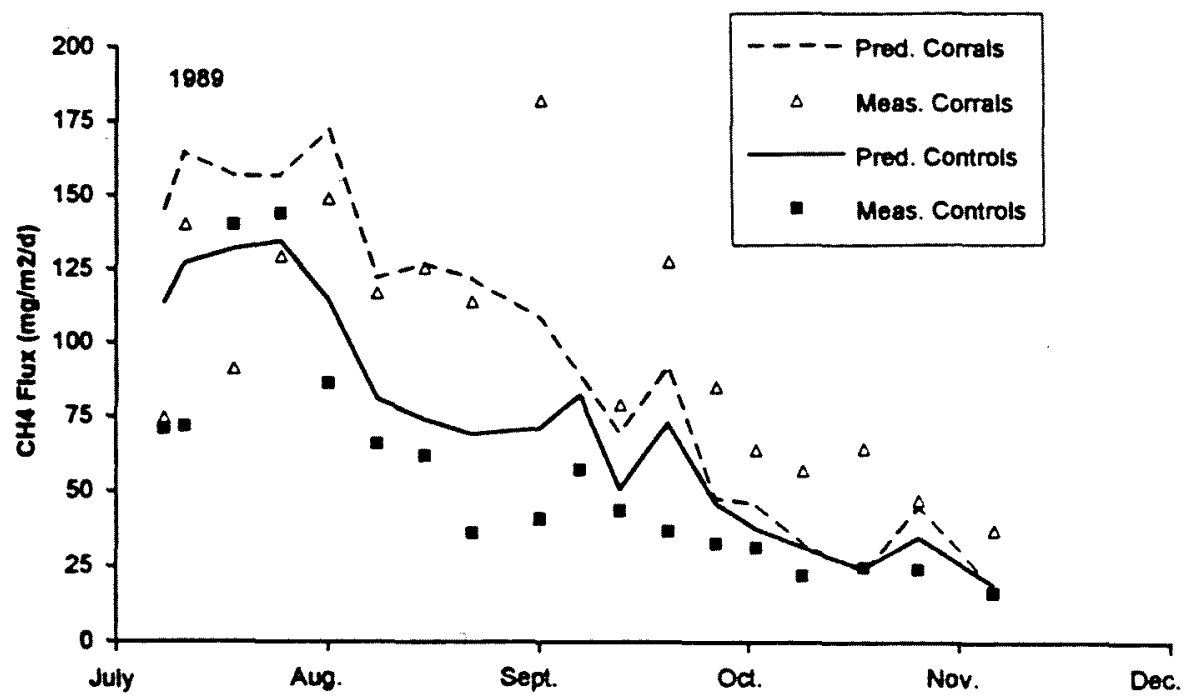

Fig. 7. Test of regression model (model $H$ in Appendix) with bog corral data, 1989. First data points are at start of experiment on July 8, 1989.

was found in the survey sites strongly suggests that methane emission in Marcell is dominated in individual ecosystems over short time periods (days to weeks) by temperature in the 10 to 30 $\mathrm{cm}$ zone (Table 1). Similar relationships between flux and temperature were found in an earlier study at Marcell [Crill et al., 1988], as well as in other studies in Canada [Moore and Knowles, 1990] and Alaska [B artett et al., 1992]. The statistical analysis suggested, somewhat surprisingly, that the controls on flux do not change over the course of the year. Regardless of season, temperature was the only important correlate with flux in individual sites, and water table was the major correlate among sites. This suggests that seasonal shifts in $\mathrm{CH}_{4}$ flux controls at Marcell do not occur and implies that in other areas a measurement program of several months may be adequate to establish the important environmental controls on flux.

The very strong relationship found between flux and the combined variables of water table and temperature across sites suggests that these environmental factors may be considered potential tools for estimating emission remotely [Matson and Vitousek, 1990] as well as for incorporation into climate change models. Evaluating this possibility would require a thorough review of existing empirical studies on flux in peatlands together with the few process-oriented investigations to resolve conflicting information about the important controls on methane emission. It remains unclear, for example, why correlations with environmental variables are higher at Marcell than those reported to date in other

TABLE 2: Comparison of calculated versus predicted total annual methane emission. Marcell Experimental Forest Peatlands, April 1989 to April 1990

Annual Methane Emission, $\mathrm{g} \mathrm{CH}_{4} \mathrm{~m}^{-2}$

\begin{tabular}{lccccc}
\cline { 3 - 6 } \multicolumn{1}{c}{ Site } & \multicolumn{2}{c}{ April 1989 to April 1990 } & & \multicolumn{2}{c}{ Sept. 1989 to Sept. 1990 } \\
& Calc. & Pred. $(N, 95 \%$ c.i. $)$ & Calc. & Pred. $(N, 95 \%$ c.i. $)$ \\
\hline Bog S-2, hummock & 3.5 & $3.2(6,2.0-5.1)$ & 2.5 & $2.4(2,-)$ \\
Bog S-2, hollow & 13.8 & $12.4(9,8.6-17.9)$ & 10.2 & $9.6(3,6.2-15.0)$ \\
Bog S-4 & 43.1 & $37.8(7,25.4-57.1)$ & 28.0 & $43.3(6,36.1-51.8)$ \\
Junction Fen & 65.7 & $58.1(6,34.1-98.9)$ & 43.9 & $59.9(5,45.6-78.6)$ \\
Mean & 31.5 & 27.9 & & 21.2 & 28.8 \\
\hline
\end{tabular}

Regression equation betweeen $\log _{\mathrm{B}} \mathrm{CH}_{4}$ flux (dependent variable) and water table, $30-\mathrm{cm}$ peat temperature, and Von Post humification index (independent variables) used. Regression model C used for April 1989 to 1990 predictions; model D used for September 1989 to 1990 predictions (in Appendix). Calc. is flux estimate calculated by integration. Pred. is predicted estimate. $N$ is the number of data points used in prediction. C.i. is the confidence interval. 


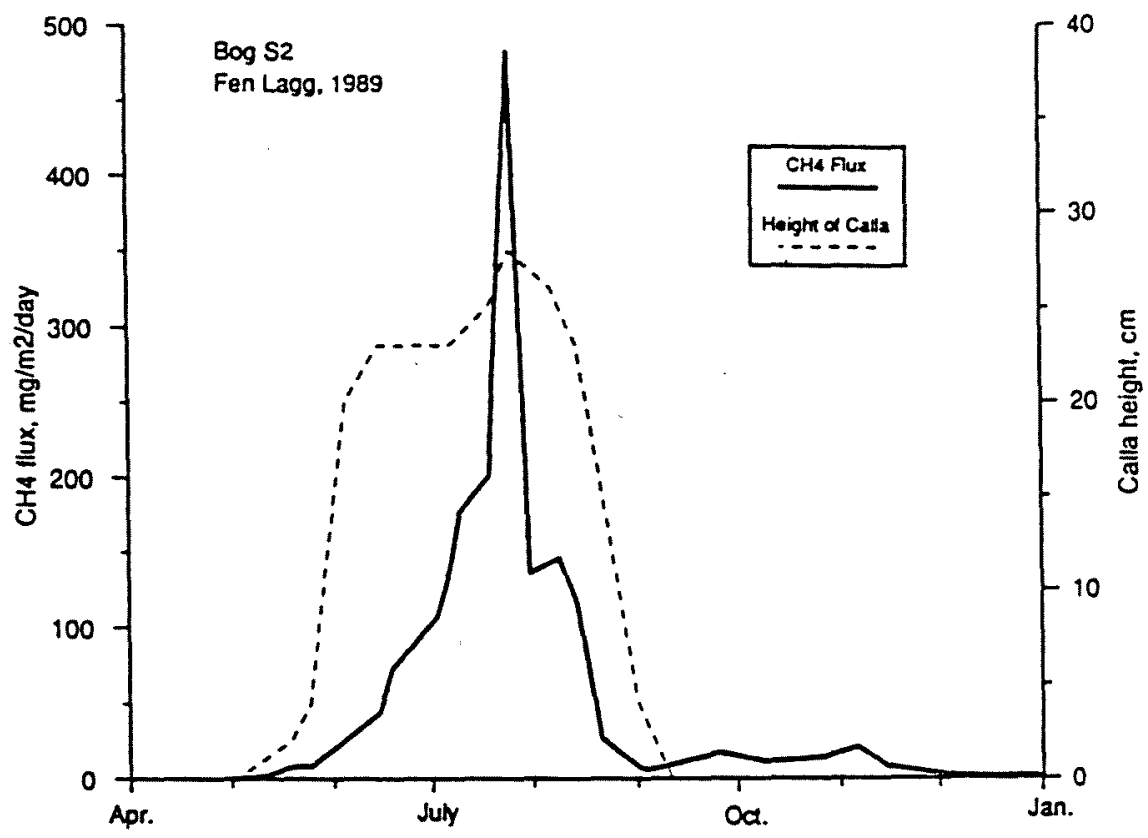

Fig. 8. Methane emission from the S-2 fen lagg site and height of Calla palustris at the site, April 1989 to January 1990.

investigations. It is encouraging that a similar but weaker relationship was also found among flux, water table and temperature in low boreal peatlands in Ontario $\left(R^{2}=0.49\right)$ [Roulet et al., 1992], indicating this simple modeling approach may be applicable to a wider region.

A second critical requirement for remote estimates is to determine how the relationship may be best expressed in a way that lends insight into processes and is a starting point for regional extrapolation. Roulet et al [1992] used mean (May to October) values of flux, peat temperature $(10 \mathrm{~cm})$ and water table from 24 sites in their model $(n=24)$ instead of the actual measurements made from each day as we have $(n=141$, model $A$ or $n=196$, model $B$ ). The advantages of their approach are that day-to-day fluctuations in emission (which can be large) due to unknown factors are reduced in importance and that using broad correlations may be the only way to apply such a model to a large region. The disadvantage is that it becomes increasingly more difficult to relate models to actual processes (and therefore to have confidence in predictions) as the data they are based on are more and more lumped. This is especially true for the processes involved in methane emission which are probably related to flux nonlinearly. Regardless of the variables used, "scaling up" a regression to incorporate different wetland regions, if at all possible, would require regionally determined climate parameters in the model: the regression generated from a low boreal region such as Marcell is useless to predict Alaska fluxes. Finally, as illustrated by the fen lagg, these across-site relationships among emission, water table and temperature may be only valid where diffusive flux through the peat can be assumed. Methane emission from areas such as rice paddies, cattail marshes or lakeshores may be most closely related to the life cycle of the emergent macrophytes.

To conclude, in these peatlands, $\mathrm{CH}_{4}$ flux was dominated locally by peat temperature in the 10 to $30-\mathrm{cm}$ zone (Table 1). Expansion of the spatial scale from individual locations to several distinct habitats within three wetlands, however, revealed the importance of water table position as the overriding factor influencing flux regionally (Figures 3 and 4). These relationships suggest two different phenomena: a long-term effect of hydrology upon the balance of methanogenic and methanotrophic bacteria population sizes and a short-term effect of temperature upon their metabolic rates. Additional influences, especially on wetter sites which may have sporadic summer pulses, can only be identified with multi-year studies in a region.

\section{APPENDIX: REGRESSION MODELS, MARCELL 1988-1990 METHANE FLUX SURVEY}

MWT 1 month (five values) running mean water table position (relative to peat hollow surface), range +5 to $-45 \mathrm{~cm}$.

T30 $30 \mathrm{~cm}$ peat temperature, range 4.5 to $20.0^{\circ} \mathrm{C}$.

VP Von Post Humification Index value, range 2 to 4 .

WT water table height, range +8 to $-51.5 \mathrm{~cm}$.

\section{Full Models}

Model A

Using running mean water table

$$
\begin{aligned}
& \log \left(\mathrm{CH}_{4} \text { flux }+1\right)= 0.0214(\mathrm{MWT})+0.0765(\mathrm{~T} 30) \\
&-0.1544(\mathrm{VP})+1.627 \\
& \mathrm{R}^{2}=0.91 ; \text { s.d. }=0.1728 ; \mathrm{n}=141
\end{aligned}
$$

Model B

Using water table measured on same date as flux measurement:

$$
\begin{array}{r}
\log \left(\mathrm{CH}_{4} \text { flux }+1\right)=0.0173(\mathrm{WT})+0.0634(\mathrm{~T} 20) \\
-0.2226(\mathrm{VP})+1.958 \\
\mathrm{R}^{2}=0.88 ; \text { s.d. }=0.2016 ; \mathrm{n}=196
\end{array}
$$


Model C

Von Post not included (for Figure $4 b$ )

$$
\begin{gathered}
\log \left(\mathrm{CH}_{4} \text { flux }+1\right)=0.0271(\mathrm{MWT})+0.0779(\mathrm{~T} 30)+1.177 \\
\mathrm{R}^{2}=0.88 ; \text { s.d. }=0.1919 ; \mathrm{n}=141
\end{gathered}
$$

\section{Split Model}

Model D

Developed on a randomly generated subsample of the entire data set, then used to predict methane concentration from the other subsample:

$$
\begin{gathered}
\log \left(\mathrm{CH}_{4} \text { flux }+1\right)=0.0213(\mathrm{MWT})+0.0772(\mathrm{~T} 30) \\
-0.1707(\mathrm{VP})+1.680 \\
\mathrm{R}^{2}=0.92 ; \text { s.d. }=0.1665 ; \mathrm{n}=71
\end{gathered}
$$

Regressions Used for Prediction of Flux at Other Sites and at Marcell in Different Years:

\section{Model E}

Regression using only 1988 to 1989 data (to predict 1990 methane fluxes at Marcell):

$$
\begin{gathered}
\log \left(\mathrm{CH}_{4} \text { flux }+1\right)=0.0202(\mathrm{MWT})+0.0796(\mathrm{~T} 30) \\
\quad-0.1873(\mathrm{VP})+1.700 \\
\mathrm{R}^{2}=0.92 ; \text { s.d. }=0.1591 ; \mathrm{n}=124
\end{gathered}
$$

Model F

Regression on full data set using $10-\mathrm{cm}$ temperature and same-day (not average) water table (to predict 1986 methane fluxes at Marcell):

$$
\begin{aligned}
& \log \left(\mathrm{CH}_{4} \text { flux }+1\right)= 0.0167(\mathrm{WT})+0.0578(\mathrm{~T} 10) \\
&-0.2296(\mathrm{VP})+2.021 \\
& \mathrm{R}^{2}=0.87 ; \text { s.d. }=0.2083 ; \mathrm{n}=207
\end{aligned}
$$

Model G

Regression on full data set using $10 \mathrm{~cm}$ temperature. no VonPost (to predict Alaska fluxes)

$$
\begin{gathered}
\log \left(\mathrm{CH}_{4} \text { flux }+1\right)=0.0277(\mathrm{MWT})+0.0557(\mathrm{~T} 10)+1.437 \\
\mathrm{R}^{2}=0.86 ; \text { s.d. }=0.2142 ; \mathrm{n}=141
\end{gathered}
$$

Model H

Regression on full data set using $10-\mathrm{cm}$ temperature (to predict bog corral fluxes)

$$
\begin{gathered}
\log \left(\mathrm{CH}_{4} \text { flux }+1\right)=0.0215(\mathrm{MWT})+0.0557(\mathrm{~T} 10) \\
-0.1772(\mathrm{VP})+1.929 \\
\mathrm{R}^{2}=0.89 ; \text { s.d. }=0.1905 ; \mathrm{n}=154
\end{gathered}
$$

A cknowledgments. We thank S. C. Whalen for the use of unpublished data and R. C. Harriss, P. M. Crill, E. Boyer, and A. Elling for advice and assistance. Special thanks to K. B. Bartlett for both scientific and editorial advice. Financial support was provided by fellowships to NBD from NASA and The Graduate School, University of Minnesota, and by a grant to EG from the Andrew W. Mellon Foundation.

\section{REFERENCES}

Aselmann. I., and P. J. Crutzen, Global distribution of natural freshwater wetlands and rice paddies, their net primary productivity, seasonality and possible methane emissions, $J$. A imos. Chem., 8, 307-358, 1989.

Bartlen, D.S., G. Sachse, P. Bakwin, K. Bartlett, D. Fizjarrald, and $\mathrm{G}$. Whiting. Regional fux estimates from synthesis of enclosure, tower, and aircraft measurements (abstracts), Eos Trans. $A G U$. $70(3), 286,1989$.

Bartlet, K.B., P.M. Crill, R.L. Sass, R.C. Harriss, and N.B. Dise, Methane emissions from tundra environments in the YukonKuskokwim delta, Alaska, J. Geophys. Res., 97, 16.645-16,660, 1992.

Bartlen, K.B., P.M. Crill, D.I. Sebacher, R.C. Harriss, J.O. Wilson, and J.M. Melack, Methane flux from the central Amazonian floodplain, J. Geophys. Res., 93(D2), 1571-1582, 1988.

Boelter, D.H. and E.S. Verry, Peatland and water in the northern lake states, USD.A For. Ser. Gen. Tech. Rep.. NC-31, 22 pp. U.S. Dep. of Agric., Washington, D.C., 1977.

Chanton, J.P., and J.W.H. Dacey, Effects of vegetation on methane flux, reservoirs, and carbon isotopic composition, in Environmental and Metabolic Controls on Trace Gas Emissions From Plamts, edited by E. Holland and H. Mooney, pp. 65-92, Academic, San Diego, Calif.. 1992

Cicerone, R.J., and R.S. Oremland. Biogeographical aspects of atmospheric methane, Global Biogeochem. Cycles, 2, 299-327, 1988.

Cicerone, R.J., and J.D. Shetter, Sources of atmospheric methane: Measurements in rice paddies and a discussion, J. Geophys. Res., 86, 7203-7209, 1981.

Crill, P.M., K.B. Bartlett, R.C. Harriss, E. Gorham, E.S. Verry, D.I. Sebacher, and L. Madzar, Methane flux from Minnesota peatlands, Global Biogeochem. Cycles, 2, 371-384, 1988.

Devore, J., and R. Peck. Statistics: The Exploration and A naly sis of Dala, West Publishing. St. Paul, Minn., 1986.

Dise, N.B., Methane emission from peatlands in northem Minnesota. Ph.D. dissertation. Univ. of Minnesota, Minneapolis, 1991.

Dise, N.B., Methane emission from Minnesota peatlands: Spatial and seasonal variability, Global Biogeochem. Cycles, 7, 123-142, 1993.

Hansen, J., A. Lacis, and M. Prather. Greenhouse effect of CFCs and other trace gases, J. Geophys. Res., 94, 16.417-16.421. 1989.

Harriss, R.C. and D.I. Sebacher, Methane flux in forested freshwater swamps of the southeastern United States, Geophys. Res. Lett., \&, 1002-1004, 1981.

Holzapfel-Pschom, A., and W. Seiler, Methane emission during a cultivation period from an Italian rice paddy, J. Geophys. Res., 91, 11.803-11,814. 1986.

Matthews, E.. and 1. Fung, Methane emission from natural wetlands: Global distribution, area and environmental characteristics of sources, Glohal Biogeochem. Cycles, 1, 61-86, 1987.

Matson, P.A.. and P.M. Vitousek, Remote sensing and trace gas fluxes. in Remot' Sensing of Biospheric Function, edited by R.J. 
Hobbs and H.A. Mooney, pp. 157-167, Springer-Verlag. New York, 1990.

Mattson, M.D., and G.E. Likens, Air pressure and methane fluxes. Nature, 347, 718-719, 1990

Moore, T.R., and R. Knowles, The influence of water table levels on methane and carbon dioxide emissions from peatland soils. Can. J. Soil Sci., 69, 33-38, 1989.

Moore, T.R., and R. Knowles, Methane emissions from fen, bog. and swamp peatlands in Quebec, Biogeochemisty, 11, 45-61, 1990.

Moore, T.R., N. Roulet, and R. Knowles, Spatial and temporal variations of methane flux from subarctic/northern boreal fens, Global Biogeochem. Cycles, 4, 29-46, 1990.

Roulet. N.T., R. Ash and T.R. Moore, Low boreal wetlands as a source of atmospheric methane, J. Geophys. Res., 97 (D4), 3739$3749,1992$.

Sebacher, D.I., R.C. Harriss, and K.B. Bartlett, Methane emissions to the atmosphere through aquatic plants, J. Environ. Qual., 14. $40-46,1985$.

Sebacher, D.I., R.C. Harriss, K.B. Bartlett, S.M. Sebacher, and S.S. Grice, Atmospheric methane sources: Alaskan tundra bogs, an alpine fen, and a subarctic boreal marsh, Tellus, 38, 1-10, 1986.

Sokal, R.R., and F.J. Rohlf, Biometry, 2nd ed., pp. 419-421, New York, 1981.

Stanek, W., and T. Silc, Comparisons of four methods for determination of degree of peat humification (decomposition) with emphasis on the Von Post method. Can. J. Soil Sci., 57. 109-117, 1977.

Verma, S.B., F.G. Ullman, D. Billesbach, R.J. Clement, J. Kim, and E.S. Verry, Eddy correlation measurements of methane flux in a northern peatland ecosystem. Boundan L ayerMeteorol., $58,289$. $304,1992$.

Verry, E.S., Streamflow chemistry and nutrient yields from uplandpeatland watersheds in Minnesota. Ecology. 56,1149-1157, 1975.

Whalen, S.C., and W.S. Reeburgh, Interannual variations in tundra methane emissions: A 4 -year time series at fixed sites, Global Biogeochem. Cycles, 6, 139-159, 1992.

Wilson, J.O., P.M. Crill, K.B. Bartlett, D.I. Sebacher, R.C. Harriss, and R.L. Sass, Seasonal variation of methane emissions from a temperate swamp. Biogeochemistry, 8. 55-71, 1989.

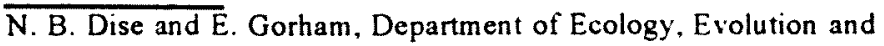
Behavior, University of Minnesota, Minneapolis, MN 55455.

E. S. Verry, U.S. Forest Service North Central Forest Experiment Station, Grand Rapids, MN 55744.

(Received August 27, 1992;

revised January 11, 1993;

accepted January 13, 1993.) 